\title{
The Consequences of Private Equity Acquisitions for Employees: New Evidence on the Impact on Wages, Employment and Productivity
}

\author{
Marc Goergen \\ Cardiff University \\ Colum Drive \\ Cardiff \\ CF10 3EU \\ Email: goergenm@cardiff.ac.uk \\ Noel O'Sullivan \\ School of Business and Economics \\ Loughborough University \\ Ashby Road \\ Loughborough \\ LE113TU \\ Email: c.n.osullivan@lboro.ac.uk \\ Geoffrey Wood \\ Warwick Business School \\ Warwick University \\ Coventry \\ CV4 7AL \\ Email: geoffrey.wood@wbs.ac.uk
}

Cardiff Business School and European Corporate Governance Institute

\begin{abstract}
There is growing controversy on the HR consequences of private equity acquisitions, especially where the existing management team is replaced. Much of the debate, thus far, has centred on the use of limited panels of case studies and industry surveys. This paper, in contrast, uses both in-depth interviews with relevant stakeholders and objective company data to compare firms subject to private equity acquisitions against a control group of non-acquired firms. Our interviews provide insights into key issues that are investigated in the subsequent empirical analysis. Our core findings are that firms subject to a specific type of private equity acquisition - Institutional Buy-Outs - are associated with job losses, lower wages and lower productivity. This evidence is consistent with the notion that this type of private equity acquisition has negative employment consequences without any corresponding improvement in productivity.
\end{abstract}

Keywords: private equity; acquisitions; employment; productivity; downsizing. 


\section{INTRODUCTION}

This is a study of the implications of private equity takeovers on employment, productivity and wages, looking specifically at the case of institutional buy-outs (IBOs). In recent years there has been increasing controversy surrounding the role of private equity acquisitions, specifically in terms of their effect on workers in the target organizations. To its proponents, the private equity industry provides new sources of funding and also helps to solve the agency problem via the reversal of value-destroying "empire building" by managers and, by doing so, disciplines and reenergises the remaining employees (Jensen, 2007). In contrast, critics argue that private equity acquisitions represent the ultimate expression of predatory financialized capital (Folkman et al., 2007), focusing on the short-term maximisation of shareholder wealth without any consideration for the interests of other stakeholders, specifically employees.

Not only is private equity a diverse phenomenon, but the evidence base for existing debates is also very diverse. Many existing studies rely on case studies (Froud and Williams, 2007a and 2007b) while others utilise surveys of representatives of the industry (see, for example, Bacon et al., 2004). In contrast, this study uses company annual reports from a sample of acquired firms both before and after the acquisition, compared against a control group of non-acquired firms. While there is much discussion as to the relative superiority of company data over subjective perceptions, with some accounts suggesting that the results are broadly comparable, and indeed interchangeable (Dess and Robinson, 1984), others have argued that industry surveys are less reliable as managers are likely to overstate performance and downplay limitations in order not to draw attention to any failings on their behalf (Bjorkman and 
Budhwar, 2007; Razouk, 2011). Although of course, with any auditable document there is a possibility of fraud, formal accounts detailing organizational performance and key organizational statistics such as size are likely to be broadly comparable within the same context, shedding light on objective trends within the organization. Indeed, Subramanian et al. (1993) found, that within the same national context, whilst better performing firms used stronger language in their reports, the broad nature of communication and factual content were comparable. In using companies' reports, this article concentrates on the quantitative data provided, hence avoiding any difficulties that may be associated with the narratives provided. Although industry surveys may, in turn, yield more detailed data than is possible to be extracted via company reports, it can be argued that, in an industry as controversial as private equity, the use of externally auditable data has considerable value, not least as it has been subject to verification by the statutory audit process. A key distinguishing feature of this study, therefore, is the use of financial information that has been subject to an external audit. The use of a control sample is crucial in order to control for the possibility that any findings emerging may simply mirror broader trends across the economy or that private equity acquirers specifically target firms with particular sets of characteristics, who, in the absence of a takeover, are likely to have encountered financial difficulties anyway.

The study adds to earlier work of the authors in that it focuses in more depth on the relationship between takeovers, jobs and wages, as well as deploying different econometric methods. In addition to this quantitative dimension, the study is supplemented by interviews with key stakeholders interested in the employment consequences of private equity acquisitions. The ability to combine both qualitative and 
quantitative research methods in the study allows us to capture a richer understanding of employee issues surrounding private equity acquisitions as well as facilitating a more balanced and objective appraisal of the empirical findings. Conducting interviews enables us to confirm whether our main research question, i.e. whether IBOs are more likely to have detrimental effects on employment than other types of private equity transactions, is appropriate. It also enables us to identify secondary factors that may influence the employment effects and that need to be controlled for in the quantitative analysis. However, in addition to simply corroborating evidence, the use of more than one method serves a purpose of providing complementary evidence (Gill and Johnson, 2010:225): the interviews shed further light on the diversity of the sector and possible differences in rationales and strategies around buy-outs.

This paper is structured as follows. We start with a brief conceptualisation of private equity and then present a summary of the underlying arguments offered in support and in opposition of private equity investment. We then discuss the findings from in-depth interviews which provide the motivation for, and additional insights into, the subsequent quantitative analysis. This is followed by a discussion of our quantitative findings. We then discuss the practical implications of our findings and in the final section we present our conclusions and map out an agenda for future research.

\section{CONCEPTUALISING PRIVATE EQUITY}

Private equity raises "capital for closed end funds organised as limited partnerships with clearly defined investment strategies, restrictive covenants setting out each investor's rights and responsibilities, and 10-13 year lock-up periods" (Cumming et al., 2011: 2). 
Wright and Wood (2009) argue that private equity encompasses different investor categories, which in turn, may lead to distinct outcomes. Private equity acquisitions are typically subdivided into management buy-outs (MBOs), management buy-ins (MBIs) and institutional buy-outs (IBOs). In MBOs, incumbent managers take the firm private, retaining their role but typically end up owning a significant proportion of the firm's equity (Wright and Wood, 2009). Additional finance is normally provided in the form of substantial levels of debt. In contrast, MBIs consist of a new management team taking the firm private, often assisted by private equity houses. Finally, IBOs are private equity acquisitions undertaken by specialist investors or investment banks, typically involving a change of management. The IBO management team does not own significant equity once the acquisition is completed.

What distinguishes private equity from venture capital is that the former tends to target more mature firms whereas the latter provides capital for early stage business ventures (Wright et al., 2009). The focus of this study is exclusively on IBOs since the change of management, a key characteristic of such acquisitions, is most likely to be associated with significant employment changes. There are two reasons why this would be the case. The first is that, as outsiders, it is easier for incoming managers to break implicit contracts with workers (Shleifer and Summers, 1988; Jensen, 2000). Second, it is expected that it is more difficult for outside managers to accurately gauge and value the worth of an organization's human assets and their combined and individual capabilities (Goergen et al. 2011; Aoki 2010). 


\section{THE CONSEQUENCES OF PRIVATE EQUITY TAKEOVERS: DEBATES AND CONTROVERSIES}

As Ernst et al. (2013) note, proponents of private equity see it as a superior ownership model opening up new routes for alternative sources of capital. Furthermore, without having to be concerned with stock prices, owners can adopt a longer term perspective. Lower levels of investment following a private equity takeover may reflect greater possibilities for leveraging and fewer information asymmetries between managers and investors while increased debt may discourage "unnecessary" investment (Ernst et al., 2013: 188). Whilst there is some evidence to suggest that the performance of many private equity funds is relatively poor, it can be argued that, without the active management role played by private equity investors, the performance of affected firms may have been even worse (Nielsen, 2011).

Baker and Anderson (2010) argue that private equity provides an effective solution to the agency problem by ensuring managers act in the interests of owners, focusing on profits rather than being distracted by other agendas. According to Jensen (2000: 11), private equity provides an "early warning system", encouraging firms to embark on "healthy" size adjustments of the workforce, reversing a historical tendency towards excess capacity, brought about not only by changes in demand but also changes in technology. Owing to the loss of prestige following on from the reversal of their "empire building", managers are likely to resist downsizing. Indeed, it may be difficult for them to objectively recognize that their firm is a high cost operator. Their replacement by a new managerial team following a private equity takeover is likely to bring greater objectivity to the process (Jensen, 2007). 
Wright et al. (2009) argue that private equity is indeed efficient in terms of reducing agency problems and enhancing cash flow; however, this account recognizes that there is much diversity within the sector. Again, it could be argued that private equity may target over-diversified firms, encouraging a narrowing of focus and a much needed specialization. Bacon et al. (2010) argue that employees may also benefit from reduced agency costs. They argue that, as managers are deterred from excessive and potentially unsustainable empire building, existing employees may be more secure in their jobs, even if this means that fewer new positions are created.

In contrast, Folkman et al. (2007) argue that the rise of private equity represents a component of a broader phenomenon - the increased prominence of financial intermediaries. The latter bring to bear an instrumentalist approach which views target organizations as stores of value waiting to be released. Such investors have less concern with actual returns in terms of sales and revenue and more with value release "hyper innovation", through selling off assets and taking on excessive debt (Folkman et al. 2007: 554). In other words, rather than reining in managerial excess, private equity takeovers benefit intermediaries at the expense of those with a stake in the long term prosperity of the firm. Westcott (2009: 533) argues that, when private equity borrows to fund a takeover, the affected firm bears the debt, exposing it to risk in the event of changes in interest rates. Hence, both existing shareholders and other stakeholders in the firm may lose out from a private equity takeover.

Clark (2013: 145) argues that such takeovers are often associated with redundancies and employee transfers, the downgrading of information sharing and consultation, and union de-recognition. In reality, although not all takeovers adopt all aspects of this 
template, a common pattern is towards decisive and far reaching restructuring, negatively impacting both managers and workers (Clark 2013). Although, for example, de-unionization may be difficult to implement, private equity fund practitioners interviewed by Clark (2013: 152) found a general hostility to extending union rights and a preference for more contingent terms and conditions of employment. In turn, the primary agenda appears to be towards enhancing fund performance, rather than organizational efficiency (ibid.). Ernst et al. (2013) argue that private equity harms the economy through paying more for target firms than other more patient investors would have since the primary focus is on the liquidation of assets, and in doing so sacrifices employees on the altar of short-term profits (Ernst et al., 2013: 181). More specifically, Clark (2007) argues that private equity takeovers are more likely to incentivise managers to act like owners (Clark, 2007: 225) while high debt places pressure on firms to outsource and to extract more value by harder human resource policies, based on examples such as the AA, Birds Eye and NCP. Pensions may be used as collateral for debts incurred by acquisitions, with deficits in pensions being met by further debt (Clarke, 2009). The pursuit of high returns makes low road HR policies attractive (Clark, 2007: 223); whilst this does not always result in immediate job shedding, the pace of the latter may be accelerated under a private equity takeover.

Not all the literature that notes such effects on HR policy is critical of the industry. For example, Jensen (2000) argues that an active market for corporate control is a highly effective force in disciplining wasteful managerial behaviour, including overstaffing. However, Appelbaum (2013: 17) sees the resultant breaking of implicit contracts as having negative consequences for organizational sustainability. As no employment 
contract can ever be complete, implicit contracts represent a cost effective way of encouraging employees to perform productively, and, hence, reneging on them may ruin a firm's capacity to stay operating through effective contracting with stakeholders (ibid.: 17). In the case of IBOs, it can be argued that managers will be particularly complicit in breaches of trust and the damage to implicit contracts particularly severe. In interviews with private equity funds, Clark (2013: 150) found that they tended to view performance outcomes primarily in terms of their investment portfolio and not the firm itself, leading to a somewhat instrumental view to other organizational stakeholders.

As can be seen from the above, a concern of a significant component of the UK literature has been on whether private equity builds value or simply redistributes it at the expense of employees, and potentially the firm itself. However, it would be incorrect to assume that all evidence falls neatly into either an optimistic or pessimistic camp. A further area of debate is whether private equity takeovers (for either the right or wrong reasons) inevitably leave employees worse off, or if they can potentially lead to mutual gains for both employers and employees. Secondly, although this study deals only with IBOs, there is a considerable body of empirical evidence that suggests that the work and employment consequences of other types of private equity funded takeover - most notably MBOs - may be more beneficial for employees (Wood and Wright, 2009; Cumming et al., 2007; Amess and Wright, 2007). General studies that combine differing manifestations of this complex phenomenon have yielded diverse results (Wood and Wright, 2009). The closest comparable study to this one - but based on US data - is Davis et al. (2011) that reported a diversity in outcomes, with the worst results for employment encountered in the service and retail sector. The overall effects on 
employment were found to be modest, with the main consequence being the reallocation of jobs between establishments in target firms (ibid.). At the same time, they found that public to private transactions involved large job losses at targets, in contrast to private equity takeovers of independent firms, i.e. private to private transactions, which yielded converse results (Davis et al. 2011: 30-31).

\section{INTERVIEW FINDINGS}

In order to understand more fully the issue at hand we decided to precede our quantitative analysis by a limited number of interviews with interested stakeholders. The aim of the interviews was to help contextualize the study and shed further light on the key issues at stake. We undertook four comprehensive interviews in 2008/9 with two trade union representatives, a representative from an independent research centre and a representative from the private equity industry. Further details on the respondents are provided at the close of this paper: interviewees were approached, the aims of the study outlined, its quantitative component explained, and informed consent sought. A standardized open ended interview schedule was employed, a copy of which is available from the authors. Three of the respondents were acknowledged critics of the industry, and, hence, it must be recognized that the balance of the interviews is tilted towards the industry's critics. However, several prominent players in the industry were approached and refused to be interviewed: non-participation may reflect respondents being ill at ease with the study's central concerns or objectives, or being uncomfortable in expressing an opinion on a particular area (Kumar 2010: 140). Here, it should be reiterated that the interviews do not aim to provide a representative view of the full 
range of alternative perspectives, but only to gain additional illumination or insights to shed further light on the principal, quantitative research findings: interviews are supplementary to the core quantitative component and the former serve for illustrative purposes and do not constitute a part of a fully-fledged triangulation of data. At the same time, we acknowledge that a more complete multi-method approach bringing to bear survey findings, company data and interviews would yield very much more nuanced insights. That, however, goes beyond the scope of a single journal article.

From a trade union perspective, private equity has often been associated with the adoption of very hardline policies against employees (Ludkin, 2008). However, there is a great deal of diversity within the private equity sector. It is recognized that privateequity backed MBOs are very different in terms of consequences for employees than IBOs (Ludkin, 2008). In the case of MBOs, those involved may be "passionate about the company, more likely to support it ... more likely to be sustainable" (Ludkin, 2008). "Venture capital is more associated with job creation, long termism; private equity with more flipping, abusive behaviour" (Ludkin, 2008).

In contrast, in the case of IBOs, there is much less interest in sustainability, and hence in higher value added human resource management (HRM) policies, and in the wellbeing of employees themselves (Ludkin, 2008). As another union representative noted, "it is IBOs that unions have been most concerned about" (Williamson, 2009). In some cases, such as in the East Anglian agricultural sector, IBOs have spearheaded cuts in wages and working conditions, which other players have mimicked (Ludkin, 2008). The industry representative felt that "the proportion of MBOs is getting smaller and smaller, meaning that IBOs are becoming proportionately more important". 
The industry representative felt that there was no reason in principle why firms should automatically get rid of employees, and, the principal opportunity identified by private equity investors was the fact that companies in this area were historically undervalued. Again, there is little evidence that employees in private equity owned companies are better or worse off than others. It could be argued that private equity often targets companies that are already in distress, so that adverse $\mathrm{HR}$ consequences are inevitable. It was generally felt that it was more difficult to renege on implicit contracts in the case of MBOs since the incumbent managers staying in place would have a closer understanding as to the precise nature of implicit contracts and the greater transaction costs should the latter be arbitrarily jettisoned. The interviewees were divided as to the nature and extent of this process in the case of IBOs. The industry interviewee felt that there was no clear pattern in this regard: "every deal is different in terms of the life cycle of the transaction and resultant managerial practices". Both union representatives felt that, in the case of IBOs, incoming management would have very little interest in such implicit contracts and would readily jettison them if need be. As Williamson (2009) argued, "there are often trade union concerns of (the effects of) new managers. There is a basic question of employment relations issues, as what is in place may be swept away." This would reflect a primary focus on formal written rules, and the extent to which they may enable or constrain a release of value to owners, and a general discounting of the role and value of informal rules and norms.

Both union representatives were of the opinion that, in the case of IBOs, a strong emphasis would be on "squeezing" labour, through leaner staffing, and, hence the intensification of work, with discipline being enforced through weaker job security. 
Furthermore, "if organizations are in debt for many years, this could negatively impact on their future capacity to reinvest in people or otherwise" (Williamson, 2009). The industry spokesperson felt "the goal is to generate returns; if sectors can benefit, there is no reason to get rid of employees without good reason". In contrast, a union representative argued "the entry of PE players has led to downward pressure on wages, mimicking of wage cutting is worse when there are limited alternative employment choices, so the effects are worse on the periphery. There is a rise of short-termism and greed, less on building" (Ludkin, 2008).

The interviews summarised above were designed to obtain more of a narrative insight into the thoughts of interested stakeholders regarding the expected/actual impact of private equity acquisitions on employees and, in so doing, to complement our empirical analysis. While some of the views are general and do not discriminate between different types of private equity acquisitions, a number of interesting views emerge that relate both to the underlying literature discussed earlier as well as the more focused results of our empirical analysis. First, there seems to be awareness among interviewees that not all private equity takeovers are equally threatening to employees with a recognition that MBOs may actually be positive (Bacon et al., 2008, 2010). The interviews reported here as well as prior research confirms the appropriateness of our focus on IBOs as they have the potential for more adverse employment consequences.

Second, our interviews also highlight the need to employ appropriate controls in our analysis. Specifically, our interviewees highlighted the need to control for industry differences since the impact of private equity acquisitions may depend on industry. Our interviews, as well as prior empirical studies, also highlight the need to control for pre- 
acquisition performance to ensure that employment effects are not due to weaker prior performance and, therefore, would be likely to have occurred with or without private equity intervention. In our empirical analysis, therefore, we use industry dummies and we also employ a sample of non-acquired firms matched with each acquired firm in terms of prior performance to ensure that any identified effects are due to the acquisition. Matching the acquired firms both by performance and industry would not have been feasible as some industries have very few firms and survivorship may also be a problem making it difficult to find appropriate non-acquired firms.

\section{QUANTITATIVE ANALYSIS}

Our initial sample consists of the 106 UK IBOs completed between 1997 and 2006. The choice of period of study implies that most of our sample (and control) firms were shielded from the negative effects of the $2007 / 8$ crisis. In other words, the global economic conditions were more benign, or in varieties of capitalism language stable, during most of our period of study than they have been in more recent years. This would suggest that, if we find detrimental effects to employment in the target firms which cannot be explained by lower productivity or higher wage costs, these effects are likely to have been even more severe post financial crisis. There were two peaks during our period of study: 1998/99 with 31 acquisitions and 2005/6 with 40 acquisitions. Data on the number of employees, turnover and wage costs are obtained from the company accounts and are collected for the six years preceding the year of the acquisition as well as the four years following that year. In what follows we refer to years preceding the 
acquisition year by negative numbers, e.g. year -1 , and to years following the acquisition by positive numbers, e.g. year 3 .

To ensure that any observed downsizing is due to the private equity acquisition and not to market wide phenomena, we compare the target firms to control firms that are not acquired. The control firms are obtained by matching each target firm with a nonacquired firm with the same performance in year -1 (or year -2 if data for year - 1 are not available) and surviving until year 2 at least. Our measure of performance is earnings before interest and tax (EBIT) divided by turnover. Except for one firm, all of the target firms can be matched with a non-acquired firm with the same performance in year -1 . Hence, our final sample is reduced to 105 IBO targets and 105 non-acquired control firms.

The focus in this section is on whether there is a decrease in employment in the targets of IBOs, after adjusting for differences in wage costs and differences in productivity between the target firms and the control firms. Our regression analysis is broadly based on the labour demand model of Nickell (1984). The model is based on companies that are subject to quadratic cost functions and Cobb-Douglas type technologies as well as output constraints. The demand for employment model can be expressed as follows:

$\mathrm{D}_{\mathrm{it}}=\alpha \mathrm{D}_{\mathrm{i}, \mathrm{t}-1}+\beta_{1} \mathrm{w}_{\mathrm{it}}+\beta_{2} \mathrm{w}_{\mathrm{i}, \mathrm{t}-1}+\delta_{1} \mathrm{Q}_{\mathrm{it}}+\delta_{2} \mathrm{Q}_{\mathrm{i}, \mathrm{t}-1}+\varphi_{\mathrm{i}}+\phi_{\mathrm{t}}+\varepsilon_{\mathrm{it}}$

where $D_{i t}, w_{i t}$, and $Q_{i t}$, are the demand for labour (measured by the logarithm ofthe number of employees), the logarithm of real wages relative to the user cost of capital 
and the logarithm of real output over value added, respectively; $\varphi_{i}, \varnothing_{t}$, and $\varepsilon_{i t}$ are unobserved, firm fixed effects, time-specific effects and an error term, respectively. ${ }^{1}$

As our focus is on the downsizing of the workforce, rather than the actual demand for employment as specified in equation (1), we estimate the equivalent logistic regression whose dependent variable is set to one if there is downsizing in a given year, and zero otherwise. $^{2}$ The independent variables in the logit are as in equation (1), except for the lagged dependent variable which is omitted given that the dependent variable (i.e. the drop in employment) is derived in part from the latter.

We include up to three indicator variables in the logit regressions which are as follows. The first indicator variable is Acquired Firm. This variable is set to one if the observation relates to a target firm, and is zero otherwise. It picks up any long-term trend in employment in the target firms which occurs independent of the acquisition. The second indicator variable is Post Acquisition. This variable is set to one for the post acquisition years for both acquired firms and matched firms, and equals zero otherwise. This variable captures a possible market-wide trend in employment during years 1 to 4 which applies to both acquired firms and matched firms. Such a trend includes a downturn in the economy which would affect firms across the board, whether they have been the target of a private equity acquisition or not. Finally, the third indicator variable is our key variable. It is the interaction of the previous two indicator variables. It measures a possible employment effect which is limited to the target firms in the post-acquisition period. If this third variable is significant and negative, then there is evidence of a reduction in employment in the target firms post-acquisition which is not observed for the control firms and which cannot merely be explained by wage and productivity 
differentials. We also include industry dummies as well as year dummies in the logit regressions.

Table 1 shows the descriptive statistics for the dichotomous dependent variable as well as the continuous independent variables. Panel A focuses on the 105 acquired firms; Panel B focuses on the 105 control firms. There are no significant differences between the proportion of acquired firms that downsize their workforce and the equivalent proportion for the control firms during the pre-acquisition period. However, there are significantly more firms among the acquired firms (0.59) that shed their workforce in year 1 than among the control firms (0.32). The difference in proportions is significant at the $1 \%$ level.

Table 1 about here

While the existing literature argues that one of the reasons for private equity acquisitions is to reduce excessive labour costs there is very little evidence of workers in target firms earning wages above the market rate pre-acquisition. Indeed, for none of the years during the pre-acquisition period are the average and median wage levels in the target firms statistically different from those in the control firms. However, during the post-acquisition period there is evidence of a drop in mean and median wages in the acquired firms. The differences in wage means and medians are significant at the $10 \%$ level in year 2 and at the $5 \%$ level in years 3 and 4.

As to turnover over employees, our measure of labour productivity, except for the averages in years -5 to -3 , the non-acquired firms are always significantly more productive (at the $5 \%$ level or better) than the acquired firms during the pre-acquisition 
period. However, the significantly lower productivity of the target firms persists after the acquisition. Except for average productivity in year 1, productivity is always significantly lower (at the $10 \%$ level or better) in the acquired firms.

Table 1 suggests that it is important to adjust for differences in both labour costs and productivity when assessing the employment effects of private equity acquisitions. Hence, our approach of estimating logistic regressions based on a labour demand model seems justified. Table 2 contains the results from the estimation of the logits. We ran four regressions; the way they differ from each other is in terms of how many of the above three indicator variables they include. In detail, regression (1) includes only the Acquired Firm indicator variable, regression (2) includes the same indicator variable as well as the Post Acquisition indicator variable, regression (3) includes all three indicator variables and regression (4) includes the Acquired Firm indicator variable as well as the interaction of the former with the Post Acquisition indicator.

\section{Table 2 about here}

Overall, the logit regressions perform well as all four continuous variables contemporaneous wage costs and productivity as well as their lags - have the correct signs and are highly significant. The Wald $\mathrm{Chi}^{2}$ is also highly significant, suggesting that the logit regression as a whole has explanatory power. The coefficient on the Acquired Firm indicator variable is not significant in any of the three regressions, suggesting that there is no evidence of downsizing in employment in the target firms which occurred irrespective of the acquisition. The Post Acquisition indicator variable (see regression (2)) is significant at the $10 \%$ level only. However, when the interaction between Post 
Acquisition and Acquired Firm is also included (see regression (3)) the Post Acquisition indicator variable is no longer significant whereas the interaction term is positive at the 5\% level. Finally, when the Post Acquisition indicator is dropped (see regression (4)) the significance of the interactive term increases to $1 \%$. This suggests that there is downsizing in the target firms subsequent to their acquisition which cannot merely be explained by differences in wage costs and productivity while there is no conclusive evidence that there is market-wide downsizing in both the target firms and control firms during the post-acquisition period.

\section{IMPLICATIONS FOR PRACTICE}

The findings of this research suggest that specific types of private equity acquisitions IBOs - are indeed detrimental to employment in the acquired firms. There is clear evidence of initial job losses after the acquisition but no evidence of increased efficiency or productivity by those employees who remain. These findings imply that private equity investors need to think more carefully about how best to maximise their wealth from taking firms private, with a particular need to think beyond just cost-cutting. Furthermore, these findings suggest that cutting employment levels, per se, also eliminates significant amounts of the accumulated knowledge and combined synergies that arise from people working together in the acquired firms, resulting in the lack of any evidence of post-acquisition improvement in performance. This, again, is something for private equity investors to carefully reflect on when considering such acquisitions. HR managers are likely, in the target organization, to be faced with the unenviable task of managing job cutting, and dealing with the knock-on consequences, ranging from the survivor syndrome to losses of expertise and capabilities. Finally, trade unionists and 
politicians are right to be concerned about the employment consequences of private equity acquisitions as the overriding finding from this study is that IBOs are associated with negative employment consequences.

\section{CONCLUSIONS}

This study explored the effects of IBOs on employment, wages and productivity. We find strong evidence of a higher incidence of downsizing in IBO targets in the year following their acquisition: this would confirm the view that at the very least such takeovers accelerate any tendency to downsize. When we adjust for differences in wage costs and differences in productivity the strong evidence of a higher likelihood of downsizing in target firms persists. Interestingly, we find evidence of lower labour costs in the target firms pre-acquisition, which persists post-acquisition, where, again, lower productivity is encountered vis-à-vis the control group; this would suggest that incoming managers neglect the human dimension, other than in terms of controlling costs. Again, this would highlight a prioritization of fund returns over HR issues, even if neglecting the latter might undermine long-term organizational sustainability. The lack of attention to enhancing productivity might suggest that the priorities of incoming managers lie elsewhere, such as, for example, financial re-engineering, and that HR issues may be of only secondary concern to enhancing returns through non-HR interventions such as the liquidation of assets or the servicing of the debt. Although there is little sign that the financial crisis has run its course, the immediate consequences have been to further favour owners of highly fungible assets over those with capital or human capabilities tied up with a particular organization or industry (Wood and Lane, 2012). Hence, it is possible that the more negative consequences of IBOs may be accentuated. Here, a 
caveat is in order; this study is of IBOs only. Studies of private equity backed MBOs suggest rather more positive results for employees (Wood and Wright, 2009); the industry is a diverse one and with similar diversity in outcomes possible.

Given that our study provides new, objective quantitative data on the impact of IBOs on employment in the UK we hope it helps stimulate further research in this contentious area. In particular, it would be really interesting to extend this analysis to other countries to see whether similar effects apply. We are also conscious that, while we follow acquired firms for four years after the acquisition, it is possible that the downsizing we document may actually improve productivity further down the line. However, our experience also suggests that it is difficult to address this completely due to the attrition of both target and control firms over time, and our interviewees were mostly sceptical as to such a possibility.

\section{Acknowledgement}

The authors would like to thank the Editor and two anonymous referees for their insightful and constructive comments and feedback. We are also grateful to the Nuffield Foundation for financial support (Social Sciences Small Grant No. 34848 on 'The Consequences of Private Equity Acquisitions for Employees'). Finally, we would also like to thank the four interviewees for their help. 


\section{Notes}

${ }^{1}$ In line with Conyon et al. (2001) real output over value added is proxied by real turnover given that the former is typically not available from the company accounts. In addition, Conyon et al. (2001) set the user cost of capital equal to one for each firm given the inherent problems with estimating this variable across firms. We do the same. Finally, we divide all of the right-hand side variables by the number of employees in the same year.

${ }^{2}$ In the companion paper, we estimate the actual equation (1), i.e. with employment in year $t$ on the left-hand side and lagged employment, i.e. employment in year $\mathrm{t}-1$, on the right-hand side. The results obtained from estimating this model are in line with those from the logit estimations. In particular, we find exactly the same results for the three indicator variables.

\section{References}

Amess K., Wright M. (2010) Leveraged buyouts, private equity and jobs. Small Business Economics 29(3): 329-349.

Amess K., and Wright M. (2007). The wage and employment effects of leveraged buyouts in the U.K. International Journal of Economics and Business, 14(2): 179-195.

Aoki, M. (2010). Corporations in Evolving Diversity. Oxford: Oxford University Press.

Appelbaum E., Batt R. and Clarke I. (2013). Implications of Financial Capitalism for Employment Relations Research: Evidence from Breach of Trust and Implicit Contracts in Private Equity Buyouts. British Journal of Industrial Relations (early access, available at: http://onlinelibrary.wiley.com/doi/10.1111/bjir.12009/full

Bacon N., Wright M, Demina N, Bruining H, and Boselie P (2008) The effects of private equity and buy-outs on HRM in the UK and the Netherlands. Human Relations 61(10): 1399-1433.

Bacon, N., Wright, M., Demina, N. (2004) Management buyouts and human resource management. British Journal of Industrial Relations, 42(2): 325-347.

Bacon N, Wright M, Scholes L, and Meuleman M (2010) Assessing the impact of private equity on industrial relations in Europe. Human Relations 63(9): 1343-1370. 
Baker K, Anderson R (2010) An overview of corporate governance. In: Baker K, Anderson R (eds.), Corporate Governance: A Synthesis of Theory, Research and Practice. Hoboken: New Jersey, 3-18.

Bjorkman I., and Budhwar P. (2007). When in Rome? Human resource management and the performance of foreign firms operating in India. Employee Relations, 29(6): 595610.

Clark I. (2013). Templates for Financial Control: Management and Employees under Private Equity. Human Resource Management Journal, 23(2): 144-159.

Clark I. (2009) Private equity in the UK: Job regulation and trade unions. Journal of Industrial Relations 51(4): 489-500.

Clark I. (2007) Private Equity and HRM in the British Business System. Human Resource Management Journal, 17(3): 218-226.

Cumming D., Fleming G., and Johan S. (2011) Institutional investment in listed private equity. European Financial Management, 17(3):594-618.

Cumming D., Siegel, D.S. and Wright, M. (2007) Private Equity, Leveraged Buyouts and Governance. Journal of Corporate Finance, 13: 439-60.

Davis S., Haltiwanger J., Jarmin R., Lerner, J. and Miranda, J. 2011. Private Equity and Employment. Working paper, University of Chicago and Harvard Business School, September 2011. Available at http://faculty.chicagobooth.edu/steven.davis/pdf/privateequityandemployment.pdf

Dess, G.G., and Robinson, R.B. (1984). Measuring organizational performance in the absence of objective measures: The case of the privately-held firm and conglomerate business unit. Strategic Management Journal, 5(3): 265-279.

Ernst S., Koziol C., and Schweizer D .(2013). Are private equity investors boon or bane for an economy? A theoretical analysis. European Financial Management, 19(1): 180207.

Folkman P, Froud J, Johal S, and Williams K (2007) Working for themselves: Financial intermediaries and present day capitalism. Business History, 49(4): 552-572.

Froud, J. and Williams, K. (2007a) Private equity and the culture of value extraction. New Political Economy, 12: 405-4.

Froud, J. and Williams, K. (2007b). New actors in a financialized economy and the remaking of capitalism. New Political Economy, 12: 339-347.

Gill, J. and Johnson, P. (2010). Research Methods for Managers $-4^{\text {th }}$ Edition. London: Sage. 
Goergen, M., O'Sullivan, N. and Wood, G. (2011). Private Equity Takeovers and Employment in the UK, Corporate Governance: An International Review, 19 (1): 259-275.

Jensen $M$ (2000) The modern industrial revolution, exit, and the failure of internal control systems. In: Jensen M (ed.) A Theory of the Firm: Governance, Residual Claims, and Organizational Forms. Boston: Harvard University Press, 16-62.

Jensen MC (2007) The economic case for private equity (and some concerns), Negotiation. Organizations and Markets Research Paper: 07-02, Harvard Business School.

Kumar, R. (2010) Research Methodology. London: Sage.

Nickell, S. (1984). An investigation of the determinants of manufacturing employment in the United Kingdom. Review of Economic Studies, 51(167): 529-558.

Nielsen K (2011) The return to direct investment in private firms. European Financial Management, 17(3): 436-463.

Razouk, A. (2011). High performance work systems and performance of French smalland medium-sized enterprises: Examining causal order. International Journal of Human Resource Management, 22(2): 311-330.

Shleifer, A. and Summers, L. (1988) Breach of trust in hostile takeovers, in Auerbach A.J. Ed, Corporate takeovers: Causes and consequences, University of Chicago Press, Chicago.

Subrmanian, R., Insley, R. and Blackwell, R. (1993). Profitability and Readability: A Comparison of Annual Reports of Profitable and Unprofitable Corporations, Journal of Business Communication, 30 (1): 49-61.

Westcott M (2009) Private equity in Australia. Journal of Industrial Relations, 51(4): 529 542.

Wood, G and Wright, M (2009) Private Equity: A review and synthesis, International Journal of Management Reviews, 11(4): 361-380.

Wood, G. and Lane, C. (2012) Institutions, Change and Diversity, Lane, C. and Wood, G. (eds.), Capitalist Diversity and Diversity within Capitalism. London: Routledge.

Wright M, Amess K, Weir C, and Gima S (2009) Private equity and corporate governance: Retrospect and prospect. Corporate Governance: An International Review 17(3): 353-375 


\section{INTERVIEWS}

1. Interview with Janet Williamson, TUC, London, January 2009. At the time of the interview, Williamson was the TUC Senior Policy Officer responsible for policy on institutional investment, corporate governance and corporate social responsibility 2. Interview with Anonymous Respondent Linked to Private Equity Industry, London, November, 2008 (anonymous 2008)

3. Interview with Maria Ludkin, GMB, London, November 2008. At the time of the interview, Ludkin was the GMB legal officer who led the GMB evidence to the Treasury Select Committee in its enquiry into the private equity industry.

4. Interview with David Hall, PSIRU, London, November 2008. The Public Service International Research Unit has conducted extensive practice orientated research on the role of private equity in privatized utilities. 


\section{Table 1: Descriptive statistics for the 105 target firms and the 105 control firms}

This table reports descriptive statistics for the sample of private equity acquisitions, i.e. the acquired firms, in Panel $\mathrm{A}$ and the control sample matched by performance in the pre-acquisitions year in Panel B. Remuneration over employees is the ratio of total wages and salaries in £000s to the annual average number of employees. Turnover over employees is the ratio of company turnover in £000s to the annual average number of employees. ${ }^{++}$stands for significance at the $1 \%$ level for the test for the difference in proportions between the acquired firms and the control firms. and ${ }^{*}$ stand for significance at the $10 \%$ and $5 \%$ level, respectively, for the t-test for the difference in means between the acquired firms and the control firms. ${ }^{\circ},{ }^{\circ}$ and ${ }^{000}$ stand for significance at the $10 \%, 5 \%$ and $1 \%$ level, respectively, for the sign rank test for the difference in medians between acquired firms and control firms.

\begin{tabular}{|c|c|c|c|c|c|c|c|c|c|c|}
\hline \multicolumn{2}{|c|}{$\begin{array}{l}\text { Year relative to acquisition } \\
\text { year (year } 0 \text { ) }\end{array}$} & -5 & -4 & -3 & -2 & -1 & 1 & 2 & 3 & 4 \\
\hline \multicolumn{2}{|c|}{$\begin{array}{l}\text { Proportion of firms with } \\
\text { decrease in employment }\end{array}$} & 0.27 & 0.31 & 0.41 & 0.37 & 0.41 & $0.59^{+++}$ & 0.48 & 0.47 & 0.55 \\
\hline \multirow{2}{*}{$\begin{array}{l}\text { Remuneration } \\
\text { over employees }\end{array}$} & Average & 21.76 & 24.48 & 25.65 & 27.46 & 29.27 & 27.94 & $30.40^{* *}$ & $30.23^{* *}$ & $33.12^{* *}$ \\
\hline & Median & 16.30 & 18.94 & 19.97 & 20.10 & 21.52 & 22.39 & $25.87^{\circ}$ & $24.75^{\circ 0}$ & $27.88^{\circ 0}$ \\
\hline \multicolumn{11}{|c|}{ Panel B: Control sample } \\
\hline \multicolumn{2}{|c|}{$\begin{array}{l}\text { Proportion of firms with a } \\
\text { decrease in employment }\end{array}$} & 0.39 & 0.40 & 0.36 & 0.36 & 0.34 & 0.32 & 0.41 & 0.51 & 0.47 \\
\hline $\begin{array}{l}\text { Remuneration } \\
\text { over employees }\end{array}$ & Average & 22.38 & 22.99 & 26.27 & 28.51 & 30.89 & 33.81 & 37.15 & 39.23 & 42.86 \\
\hline
\end{tabular}




\section{Table 2: Logistic Regressions Explaining Likelihood of Downsizing}

The dependent variable is set to if there is a decrease in the average number of employees in year t relative to year $\mathrm{t}-1$, and zero otherwise. Log (Remuneration over Employees) is the logarithm of the ratio of total wages and salaries in $£ 000$ s to the annual average number of employees both measured in year t. Log (Turnover over Employees) is the logarithm of the ratio of company turnover in £000s to the annual average number of employees both measured in year t. Acquired Firm is an indicator variable which equals one if the firm is a private equity target, and zero otherwise. Post Acquisition is an indicator variable which is set to one for all firm-year observations following the year of the acquisition. Post Acquisition * Acquired Firm is the interaction of the previous two indicator variables. All regressions include industry dummies as well as year dummies (not reported in the table). The figures in parentheses are the z-statistics. , and stand for statistical significance at the $1 \%$, $5 \%$ and $10 \%$ level, respectively.

\begin{tabular}{|c|c|c|c|c|}
\hline & (1) & (2) & (3) & (4) \\
\hline Log (Remuneration over Employees $\left.{ }_{t}\right)$ & $\begin{array}{c}0.938 \\
(2.77)\end{array}$ & $\begin{array}{c}0.974 \\
(2.87)\end{array}$ & $\begin{array}{c}0.974 \\
(2.86)\end{array}$ & $\begin{array}{c}0.968 \\
(2.85)\end{array}$ \\
\hline Log (Remuneration over Employees $\mathrm{t}_{\mathrm{t}-1}$ ) & $\begin{array}{c}-0.883^{\times x \pi} \\
(-2.60)\end{array}$ & $\begin{array}{c}-0.877^{m \times x} \\
(-2.58)\end{array}$ & $\begin{array}{c}-0.867^{* \pi} \\
(-2.55)\end{array}$ & $\begin{array}{c}-0.867^{*} \\
(-2.55)\end{array}$ \\
\hline Log (Turnover over Employees ${ }_{t}$ ) & $\begin{array}{c}0.805^{n \times x} \\
(3.13)\end{array}$ & $\begin{array}{c}0.776^{\pi \times \pi} \\
(3.00)\end{array}$ & $\begin{array}{c}0.791^{\times \times x} \\
(3.05)\end{array}$ & $\begin{array}{c}0.797^{n \times x} \\
(3.08)\end{array}$ \\
\hline Log (Turnover over Employees $\mathrm{t}_{\mathrm{t}-1}$ ) & $\begin{array}{c}-0.843^{x \times x} \\
(-3.29)\end{array}$ & $\begin{array}{c}-0.829^{x \times x} \\
(-3.22)\end{array}$ & $\begin{array}{c}-0.848^{x \times x} \\
(-3.29)\end{array}$ & $\begin{array}{c}-0.851^{\pi \times \star} \\
(-3.31)\end{array}$ \\
\hline Acquired Firm & $\begin{array}{l}0.131 \\
(1.16)\end{array}$ & $\begin{array}{l}0.144 \\
(1.26)\end{array}$ & $\begin{array}{l}-0.061 \\
(-0.42)\end{array}$ & $\begin{array}{l}-0.081 \\
(-0.59)\end{array}$ \\
\hline Post Acquisition & - & $\begin{array}{l}0.287^{*} \\
(1.85)\end{array}$ & $\begin{array}{c}0.0670 \\
(0.36)\end{array}$ & - \\
\hline Post Acquisition $x$ Acquired Firm & - & - & $\begin{array}{l}0.508^{\mathrm{xx}} \\
(2.23)\end{array}$ & $\begin{array}{c}0.552^{n \times x} \\
(2.87)\end{array}$ \\
\hline Constant & $\begin{array}{l}0.140 \\
(0.18)\end{array}$ & $\begin{array}{l}0.048 \\
(0.06)\end{array}$ & $\begin{array}{l}0.132 \\
(0.17)\end{array}$ & $\begin{array}{l}0.155 \\
(0.20)\end{array}$ \\
\hline $\begin{array}{l}\mathrm{N} \\
\text { Pseudo } \mathrm{R}^{2} \\
\text { Wald Chi }^{2} \\
\text { Degrees of freedom }\end{array}$ & $\begin{array}{c}1522 \\
0.072 \\
147.5 \\
31\end{array}$ & $\begin{array}{c}1522 \\
0.073 \\
150.9 \\
32\end{array}$ & $\begin{array}{c}1522 \\
0.076 \\
155.9 \\
33\end{array}$ & $\begin{array}{c}1522 \\
0.076 \\
155.8 \\
32\end{array}$ \\
\hline
\end{tabular}

